\title{
Winter Rye Cover Crop with Liquid Manure Injection Reduces Spring Soil Nitrate but Not Maize Yield
}

\author{
Leslie A. Everett ${ }^{1}$, Melissa L. Wilson ${ }^{2} \oplus$, Randall J. Pepin ${ }^{3}$ and Jeffrey A. Coulter ${ }^{4, *}$ \\ 1 Water Resources Center, University of Minnesota, St. Paul, MN 55108-6028, USA; evere003@umn.edu \\ 2 Department of Soil, Water, and Climate, University of Minnesota, St. Paul, MN 55108-6028, USA; \\ mlw@umn.edu \\ 3 University of Minnesota Extension, University of Minnesota, St. Paul, MN 55108-6028, USA; \\ pepin019@umn.edu \\ 4 Department of Agronomy and Plant Genetics, University of Minnesota, St. Paul, MN 55108-6028, USA \\ * Correspondence: jeffcoulter@umn.edu; Tel.: +1-612-625-1796
}

Received: 25 November 2019; Accepted: 3 December 2019; Published: 5 December 2019

\begin{abstract}
In maize-based cropping systems, leaching of nitrate-nitrogen $\left(\mathrm{NO}_{3}-\mathrm{N}\right)$ to drainage tile and groundwater is a significant problem. The purpose of this study was to assess whether a winter rye cover crop planted after silage maize or soybean harvest and injected with liquid manure could decrease soil $\mathrm{NO}_{3}-\mathrm{N}$ without reducing the yield of the following maize crop. An experiment was conducted at 19 sites with predominant occurrence of Mollisols (15 out of 19 sites) in the upper Midwest USA immediately after soybean or maize silage harvest to compare a drilled rye cover crop and a non-cover crop control. Later in the fall, liquid swine or dairy manure was injected into the cover crop and control plots. Rye was terminated the following spring using herbicide, usually before reaching 20 to $25 \mathrm{~cm}$ in height, and incorporated with tillage at most sites, after which maize was planted and harvested as silage or grain. Across sites, soil $\mathrm{NO}_{3}-\mathrm{N}$ at rye termination was reduced by $36 \%$ (range $=4 \%$ to $67 \%$ ) with rye compared to no rye. Nitrogen in aboveground rye biomass at termination ranged from 5 to $114 \mathrm{~kg} \mathrm{~N} \mathrm{ha}^{-1}$ (mean $=51 \mathrm{~kg} \mathrm{~N} \mathrm{ha}^{-1}$ ). Across sites, there was no significant difference in yield of maize silage or grain between treatments. These results demonstrate in a Mollisol-dominated region the potential of a winter rye cover crop planted before manure application to effectively reduce soil $\mathrm{NO}_{3}-\mathrm{N}$ without impacting yield of the following maize crop, thereby reducing risk of negative environmental impacts.
\end{abstract}

Keywords: cover crop; manure; nitrate; nitrogen; cereal rye; maize

\section{Introduction}

Agricultural intensification over the past few decades has led to degradation of aquatic systems, and the impact of downstream nutrient export from agricultural lands continues to be of concern. Nitrate-nitrogen $\left(\mathrm{NO}_{3}-\mathrm{N}\right)$ is particularly troublesome as it leaches through the soil into subsurface drainage or groundwater, which ultimately leads to surface waters. There are now over 400 aquatic systems across the world experiencing hypoxia due to excess nutrients fueling algal blooms [1].

In the Midwest region of the United States, nutrient losses have been exacerbated by both intensified crop and livestock production. This has led to a large hypoxic, or dead, zone forming annually in the Gulf of Mexico [2,3]. In cropping systems, the use of commercial fertilizers along with increased mineralization of nitrogen from drained soils is problematic [4-6]. Where animal feeding operations have concentrated, the amount of manure often exceeds the nearby cropland nutrient needs and manure is treated as more of a waste rather than a resource [7,8]. As an example, the US Department of Agriculture's (USDA) Agricultural Resource Management Survey found that 
95\% of manure applications to maize (Zea mays L.) acres did not follow national recommendations for application rate, timing, and placement [9]. In Minnesota, USA, where the headwaters of the Mississippi River, which constitutes a major inflow to the Gulf of Mexico, are located, the 2-year maize-soybean (Glycine max (L.) Merr.) rotation dominates the agricultural landscape, similar to most places in the Midwest [10]. A survey of Minnesota growers found that those using manure applied on average $25.6 \mathrm{~kg}$ per hectare more $\mathrm{N}$ than recommended for maize [11], and overapplications most notably occurred where maize followed soybean [12].

In the upper Midwest USA, the cold climate adds further challenges to manure management. Due the short growing season and increasingly wet springtime conditions [13], liquid swine (Sus scrofa L.) and dairy cow (Bos taurus L.) manure are frequently applied in the fall prior to planting maize the following spring. However, maize does not begin taking up substantial amounts of nitrogen $(\mathrm{N})$ until the mid-vegetative stages [14]. This creates risk of soil nitrate-nitrogen leaching below the maize rooting zone, since most of the $\mathrm{N}$ in liquid swine manure and about one-half in liquid dairy manure is ammonium [15], which is rapidly converted to $\mathrm{NO}_{3}-\mathrm{N}$ when the soil temperature in the zone of application exceeds $10^{\circ} \mathrm{C}$ [16]. This challenge is exacerbated when warm weather and excess precipitation occur between manure application and maize $\mathrm{N}$ uptake $[5,17,18]$, which are expected to occur more frequently with climate change [19].

One strategy for managing excess $\mathrm{N}$ in soil between cash crops includes using cover crops to take up $\mathrm{N}$ and release it following termination. It has been well established that grasses are particularly effective at scavenging $\mathrm{N}$ and holding it in the biomass that is produced [20-24], although it is questionable whether $\mathrm{N}$ release from the cover crop biomass will synchronize with maize uptake the following growing season. Huntington et al. reported that in a no-till system, $\mathrm{N}$ release from hairy vetch (Vicia villosa Roth) and rye (Secale cereale L.) was typically highest after the maize silking stage and thus did not synchronize well with maize uptake [25]. Jahanzad et al. found that forage radish (Raphanus sativus L.) and winter pea (Pisum sativum subsp. arvense L.) decomposed much more quickly than rye and $\mathrm{N}$ release was more synchronized with early cash crop $\mathrm{N}$ demands, but they also reported that rye had faster decomposition and $\mathrm{N}$ release when buried in the soil as opposed to being left on the soil surface after being terminated [26]. In some cases, this lack of synchronization may cause losses in maize yield [27], but on the other hand, many studies have reported minimal or even positive impacts on yields following grass cover crops over the long term [28-31], particularly when fertilization regimes were optimized [32].

Most studies have evaluated cover crops in systems utilizing commercial fertilizers, but few studies have evaluated use with fall-applied manure. In Ontario Canada, fall cover crops of perennial ryegrass (Lolium perenne L.), oat (Avena sativus L.), and red clover (Trifolium pratense L.) reduced residual soil mineral $\mathrm{N}$ by $26 \%$ to $42 \%$ compared to no cover crop after fall-applied liquid swine manure, but the following year maize grain yield was reduced by up to $15 \%$ [33]. In Iowa, USA, Singer et al. found that a rye-oat mixture interseeded into soybean reduced soil $\mathrm{NO}_{3}-\mathrm{N}$ in the $0-30 \mathrm{~cm}$ depth during the early growing season of maize without affecting maize grain yield after liquid swine manure was injected into the growing cover crop the previous fall [34]. In Pennsylvania, USA, maize yields were highest when manure was injected in late fall (November) into a rye cover crop compared with rye being planted after an early application of manure in September, and furthermore, manure injected into the cover crop resulted in better yields than when manure was simply broadcast onto the cover crop [35]. These findings have practical implications for growers because it is counterintuitive to plant a cover crop and then reduce biomass by injecting liquid manure into it.

While there have been some promising results when adding cover crops as a best management practice for fall manure application, this practice has not been evaluated in a cold climate, i.e., the upper Midwestern USA. It is unclear how results from other studies would transfer to this region when the short growing season adds additional constraints. Furthermore, practical applications for growers need to be considered because there has been little reported research conducted on working farms with large scale equipment. To convince growers of the merit of this practice and to increase adoption 
rates, more on-farm research is needed. The objective of this study was to assess whether a winter rye cover crop planted after silage maize or soybean harvest and injected with liquid swine or dairy manure in the fall could decrease soil $\mathrm{NO}_{3}-\mathrm{N}$ without reducing yield of the following maize crop.

\section{Materials and Methods}

A field experiment was conducted across 15 on-farm and four research station sites in southern and central Minnesota during the 2016 and 2017 maize growing seasons. A composite soil sample from the 0-15 cm depth was collected from each site prior to applying treatments and analyzed for phosphorus (Olsen or Bray-1) [36,37], ammonium acetate extractable potassium [38], $\mathrm{pH}$ (1:1 soil:water) [39], and organic matter (combustion) [40]. Soil classification, texture, and initial soil-test levels are in Table S1. Soils were Mollisols with 27 to $83 \mathrm{~g} \mathrm{~kg}^{-1}$ organic matter in the $0-15 \mathrm{~cm}$ depth at 15 sites and Alfisols with 30 to $52 \mathrm{~g} \mathrm{~kg}^{-1}$ organic matter in the $0-15 \mathrm{~cm}$ depth at four sites.

The two treatments were winter rye cover crop and no cover crop, replicated three times within a randomized complete block design, and established immediately following maize silage or soybean harvest the year prior to the main crop growing season. All agronomic practices other than cover crop planting were consistent between treatments at all locations. At sites where the manure type (Table 1) was swine, the prior crop was soybean, and where the manure type was dairy, the prior crop was maize except for site 12 where it was soybean. Plots were equal to or greater in width than the cooperating growers' maize harvester, and were 4.6 to $6.7 \mathrm{~m}$ wide by 73.2 to $170.7 \mathrm{~m}$ long at the on-farm sites, and $1.5 \mathrm{~m}$ wide by $12.2 \mathrm{~m}$ long at the research station sites (sites $3,8,13$, and 19). Rye was planted at $100 \mathrm{~kg} \mathrm{ha}^{-1}$ by the cooperating growers using a grain drill. Rye was planted between late September and early November (Table 1). Aboveground biomass of rye in the fall was limited, especially with the later seeding dates, and therefore not measured.

Table 1. Dates of field operations, manure type, and maize harvest method at the 19 experimental sites.

\begin{tabular}{|c|c|c|c|c|c|c|}
\hline Site & $\begin{array}{c}\text { Rye Planting } \\
\text { Date }\end{array}$ & $\begin{array}{l}\text { Manure } \\
\text { Type }\end{array}$ & $\begin{array}{c}\text { Manure } \\
\text { Application Date }\end{array}$ & $\begin{array}{c}\text { Rye Sampling } \\
\text { Date }\end{array}$ & $\begin{array}{c}\text { Maize Planting } \\
\text { Date }\end{array}$ & $\begin{array}{c}\text { Maize Harvest } \\
\text { Method }\end{array}$ \\
\hline & \multicolumn{3}{|c|}{2015} & \multicolumn{3}{|c|}{2016} \\
\hline 1 & 30 September & dairy & 20 November & 26 April & 6 May & silage \\
\hline 2 & 26 September & dairy & 9 October & 18 April & 4 May & silage \\
\hline 3 & 9 October & dairy & 12 November & 15 April & 3 May & grain \\
\hline 6 & 3 October & swine & 10 November & 22 April & 6 May & grain \\
\hline 7 & 29 September & swine & 12 November & 22 April & 25 April & grain \\
\hline 8 & 9 October & swine & 12 November & 15 April & 3 May & grain \\
\hline \multirow[t]{2}{*}{9} & 12 October & swine & 10 November & 26 April & 7 May & grain \\
\hline & \multicolumn{3}{|c|}{2016} & \multicolumn{3}{|c|}{2017} \\
\hline 13 & 26 October & dairy & 5 December & 24 April & 15 May & grain \\
\hline 14 & 17 October & dairy & 6 October & 9 May & 10 May & silage \\
\hline 15 & 7 October & dairy & 22 October & 25 April & 11 May & silage \\
\hline 16 & 8 November & swine & 25 October & 8 May & 9 May & grain \\
\hline 17 & 14 October & swine & 18 October & 20 April & 6 May & grain \\
\hline 18 & 17 October & swine & 27 November & 17 April & 9 May & grain \\
\hline 19 & 26 October & swine & 5 December & 24 April & 15 May & grain \\
\hline
\end{tabular}

Liquid swine or dairy cow manure was injected into the soil of the cover crop and no cover crop treatments two to six weeks after the winter rye was planted, at most sites. However, in 2016, manure application occurred three to four days after rye planting at two sites, and 11 to 14 days before planting at two sites (Table 1). Manure application equipment included disk closures without knives (sites 6, 12), knives without terminal sweeps (sites 1,2,14), and knives with terminal sweeps narrower 
than $30 \mathrm{~cm}$ (all other sites). Manure was placed approximately 8 to $10 \mathrm{~cm}$ deep with the disk closures alone and 13 to $20 \mathrm{~cm}$ deep with knives. The manure application rate at each site was determined by the cooperating growers. A manure sample from each site was analyzed for total Kjeldahl $\mathrm{N}$ and inorganic $\mathrm{N}$ following methods of Peters et al. [41] on a continuous flow gas diffusion and conductivity

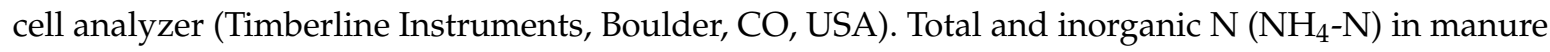
and $\mathrm{N}$ from fertilizer are in Table 2. The forms, rates, and dates of application of mineral fertilizers applied are in Table S2. At all sites but three (sites 3, 8, 13), manure was the principal N source. At the three sites where it was not, manure had not been agitated and its $\mathrm{N}$ content was low $\left(0.36-0.48 \mathrm{~g} \mathrm{~L}^{-1}\right)$, so fertilizer $\mathrm{N}$ applied in the spring after cover crop termination was the dominant $\mathrm{N}$ source.

Table 2. Total nitrogen $\left(\mathrm{kg} \mathrm{ha}^{-1}\right)$ applied, plant nitrogen $(\mathrm{N})$ measured in the aboveground rye biomass at termination and in the maize plants at harvest (silage or grain, plus dry stalks), and soil nitrate-N $\left(0-60 \mathrm{~cm}, \mathrm{mg} \mathrm{kg}^{-1}\right)$ measured at cover crop termination.

\begin{tabular}{|c|c|c|c|c|c|c|c|c|}
\hline \multirow{3}{*}{ Site } & \multicolumn{3}{|c|}{ Total N Applied } & \multicolumn{3}{|c|}{ Plant N Uptake } & \multicolumn{2}{|c|}{ Soil $\mathrm{NO}_{3}-\mathrm{N}$} \\
\hline & \multicolumn{2}{|c|}{ Manure } & \multirow[t]{2}{*}{ Fertilizer } & \multirow[t]{2}{*}{ Rye } & \multicolumn{2}{|c|}{ Maize } & \multirow[t]{2}{*}{ w/Rye } & \multirow[t]{2}{*}{ w/o Rye } \\
\hline & TKN * & $\mathrm{NH}_{4}-\mathrm{N}$ & & & w/Rye & w/o Rye & & \\
\hline & \multicolumn{6}{|c|}{ kg ha $a^{-1}$} & \multicolumn{2}{|c|}{$\mathrm{mg} \mathrm{kg}^{-1}$} \\
\hline \multicolumn{9}{|c|}{2016 Maize Growing Season } \\
\hline 1 & 256 & 222 & 0 & $95(14.2) \dagger$ & $85(5.8)$ & $120(5.9)$ & $4(0.8)$ & $12(1.3)$ \\
\hline 2 & 179 & 142 & 0 & $98(19.2)$ & $193(15.8)$ & $188(11.2)$ & $24(2.3)$ & $26(3.0)$ \\
\hline 3 & 30 & 7 & 157 & $15(1.2)$ & $139(13.7)$ & $135(19.4)$ & $6(0.6)$ & $9(0.3)$ \\
\hline 4 & 186 & 177 & 28 & $107(1.5)$ & $151(4.1)$ & $149(2.5)$ & $16(1.3)$ & $21(5.0)$ \\
\hline 5 & 320 & 232 & 36 & $114(11.2)$ & $186(4.9)$ & $177(12.5)$ & $7(1.5)$ & $21(3.0)$ \\
\hline 6 & 226 & 209 & 0 & $84(2.9)$ & $177(14.9)$ & $177(12.8)$ & $20(1.2)$ & $38(2.8)$ \\
\hline 7 & 219 & 217 & 0 & $71(6.0)$ & $152(18.2)$ & $136(2.5)$ & $12(1.4)$ & $25(2.5)$ \\
\hline 8 & 22 & 20 & 112 & $14(0.3)$ & $148(11.7)$ & $142(8.9)$ & $7(0.3)$ & $11(0.4)$ \\
\hline 9 & 75 & 73 & 0 & $43(4.0)$ & $91(6.6)$ & $99(1.8)$ & $4(0.3)$ & $10(1.5)$ \\
\hline \multicolumn{9}{|c|}{2017 Maize Growing Season } \\
\hline 10 & 279 & 118 & 0 & $84(4.2)$ & $209(5.2)$ & $218(6.2)$ & $7(1.8)$ & $13(1.5)$ \\
\hline 11 & 292 & 105 & 0 & $22(2.8)$ & $188(7.4)$ & $185(15.6)$ & $18(2.2)$ & $27(0.8)$ \\
\hline 12 & 148 & 68 & 68 & $49(0.3)$ & $144(1.5)$ & $149(3.5)$ & $24(3.0)$ & $35(4.4)$ \\
\hline 13 & 24 & 14 & 135 & $5(0.3)$ & $153(9.2)$ & $153(6.0)$ & $13(1.5)$ & $14(1.2)$ \\
\hline 14 & 195 & $\ddagger$ & 68 & $54(2.6)$ & $144(6.3)$ & $170(8.2)$ & $9(1.2)$ & $15(1.6)$ \\
\hline 15 & 374 & 169 & 35 & $25(1.7)$ & $166(13.3)$ & $167(2.9)$ & $27(4.6)$ & $28(1.4)$ \\
\hline 16 & 226 & 137 & 86 & $5(1.0)$ & $156(4.7)$ & 165 (14.5) & $23(0.4)$ & $35(4.8)$ \\
\hline 17 & 140 & 100 & 0 & $65(4.4)$ & 141 (11.0) & $144(1.7)$ & $10(2.0)$ & $20(1.2)$ \\
\hline 18 & 186 & 127 & 67 & $8(0.5)$ & $174(3.6)$ & $163(5.6)$ & $44(4.7)$ & $64(12.6)$ \\
\hline 19 & 206 & 153 & 0 & $5(0.3)$ & $181(8.9)$ & $180(10.0)$ & $22(3.9)$ & $56(16.1)$ \\
\hline \multicolumn{4}{|c|}{ Mean } & $49(5.2)$ & $157(4.5)$ & $159(4.0)$ & $16(1.4)$ & $25(2.2)$ \\
\hline Signifi & of diffe & e with a & thout rye & & & & \multicolumn{2}{|c|}{$p<0.001$} \\
\hline
\end{tabular}

* Total Kjeldahl nitrogen. † Standard error is shown within parentheses. $\ddagger$ Not measured. n.s. = not significantly different.

Spring cover crop termination was targeted to be prior to rye reaching a $25 \mathrm{~cm}$ height to ensure that $\mathrm{N}$ uptake by rye did not reduce soil $\mathrm{N}$ below the level required by the subsequent maize crop during the early growing season [42]. Rye was terminated by herbicide followed by full-width tillage at all sites except three: at site 9, herbicide was followed by strip-tillage, and at sites 14 and 16, termination was by full-width tillage only. Agronomic practices for cover crop termination were also applied to plots of the no cover crop treatment at all sites. At rye termination, rye canopy height, plant density, aboveground biomass, and $\mathrm{N}$ concentration, as well as soil $\mathrm{NO}_{3}-\mathrm{N}$ in the $0-60 \mathrm{~cm}$ layer, were measured. The average height of the rye canopy at each site was recorded. At three or four random locations per replication a $0.25 \mathrm{~m}^{2}$ quadrat was delineated, plants were counted and cut at the soil surface, combined, weighed, subsampled, weighed, and then oven-dried at $60^{\circ} \mathrm{C}$ until constant mass, weighed, ground to pass a 1-mm sieve, and analyzed for Kjeldahl N. Depending on plot length, 8 to 12 soil cores were 
randomly collected from the 0-60 cm depth in each plot, mixed, sub-sampled, oven-dried at $35^{\circ} \mathrm{C}$ until constant mass, ground to pass a 2-mm sieve, and analyzed for $\mathrm{NO}_{3}-\mathrm{N}(\mathrm{KCl}$ extraction and cadmium reduction method) [43,44].

Maize was planted in 76-cm rows at 18 sites and in 56-cm rows at one site (site 16) and managed by cooperating growers. Maize hybrids and planting rates varied among sites and were selected by the cooperating growers. Some sites received supplemental $\mathrm{N}$ fertilizer at rates determined by the growers (Table 2). Maize was harvested by the growers as silage at eight sites and as grain at 11 sites. Silage yield was measured by weighing the silage wagon before and after chopping each plot. For each plot, a $\sim 0.5-\mathrm{kg}$ sample of the silage was weighed, oven-dried at $35^{\circ} \mathrm{C}$ until constant mass, reweighed, ground to pass a 2-mm sieve, and analyzed for Kjeldahl N. At sites where maize was harvested for grain, grain yield was measured using a calibrated weigh wagon and samples were taken for laboratory determination of moisture and Kjeldahl N. Silage and grain yields were calculated at 650 and $155 \mathrm{mg} \mathrm{kg}^{-1}$ moisture content, respectively. Prior to machine harvest for grain, 20 plants were randomly selected from each plot, cut at the soil surface, ears removed, stalks and husk weighed, chopped, mixed, subsampled, weighed, oven-dried at $35^{\circ} \mathrm{C}$ until constant mass, reweighed, ground to pass a 2-mm sieve, and analyzed for Kjeldahl N.

Monthly precipitation and average air temperature for August 2015 through November 2017 were collected from nine National Weather Service weather stations in Minnesota (Midwestern Regional Climate Center, Champaign, IL, USA) and compared to the 30-year average (1981-2010). Stations were chosen based on proximity to study sites and availability of 30-year data. To show the general trends in weather patterns over the study, data were averaged across weather stations.

Data were analyzed at $p \leq 0.05$ with JMP version 13 Pro (SAS Institute Inc., Cary, NC, USA) using standard least squares (restricted maximum likelihood method, REML) and linear regression. Treatment was considered a fixed effect and site and replication (nested within site), and site $\times$ treatment were considered random effects. Site means for aboveground rye dry matter yield (DM) at termination were regressed on rye planting day of the year and on canopy height. Nitrogen concentration in aboveground rye was regressed on rye aboveground $\mathrm{DM}$ and rye height. Total rye $\mathrm{N}$ was regressed on rye $\mathrm{DM}$ and rye $\mathrm{N}$ concentration. The difference in soil $\mathrm{NO}_{3}-\mathrm{N}$ between cover cropped and bare plots was regressed on the number of days between rye planting and manure application. Rye plant density, rye $\mathrm{DM}$, concentration of $\mathrm{N}$ in aboveground rye, and total $\mathrm{N}$ in aboveground rye were analyzed by site. An inspection of residuals indicated that the assumption of normality was met. Soil $\mathrm{NO}_{3}-\mathrm{N}\left(\mathrm{mg} \mathrm{kg}^{-1}\right)$, maize grain yield, stalk DM, silage yield, grain $\mathrm{N}\left(\mathrm{kg} \mathrm{ha}^{-1}\right)$, stalk $\mathrm{N}$, silage $\mathrm{N}$, and total above ground plant $\mathrm{N}$ were each analyzed for rye and no rye treatments separately across sites. Those variables were analyzed individually across sites and treatments. Soil $\mathrm{NO}_{3}-\mathrm{N}$ was also analyzed for rye and no rye treatments when maize was the forecrop versus soybean and also when swine manure was used versus dairy. An inspection of residuals indicated that the assumption of normality was met.

\section{Results}

\subsection{Weather}

Monthly precipitation and air temperature data from this study are compared to the 30-year average (1981-2010) in Figure 1. In 2015 when the cover crop was planted (September through October), the weather tended to be warmer and drier than the 30-year average. This allowed for good field conditions for harvest of the prior crop, and the cover crops were planted earlier than in 2016 (Table 1). While temperatures were warmer than the 30-year average in the fall of 2016, harvest of the crop prior to the cover crop was delayed in many fields due to excessively wet conditions, thus delaying planting of the cover crop. 


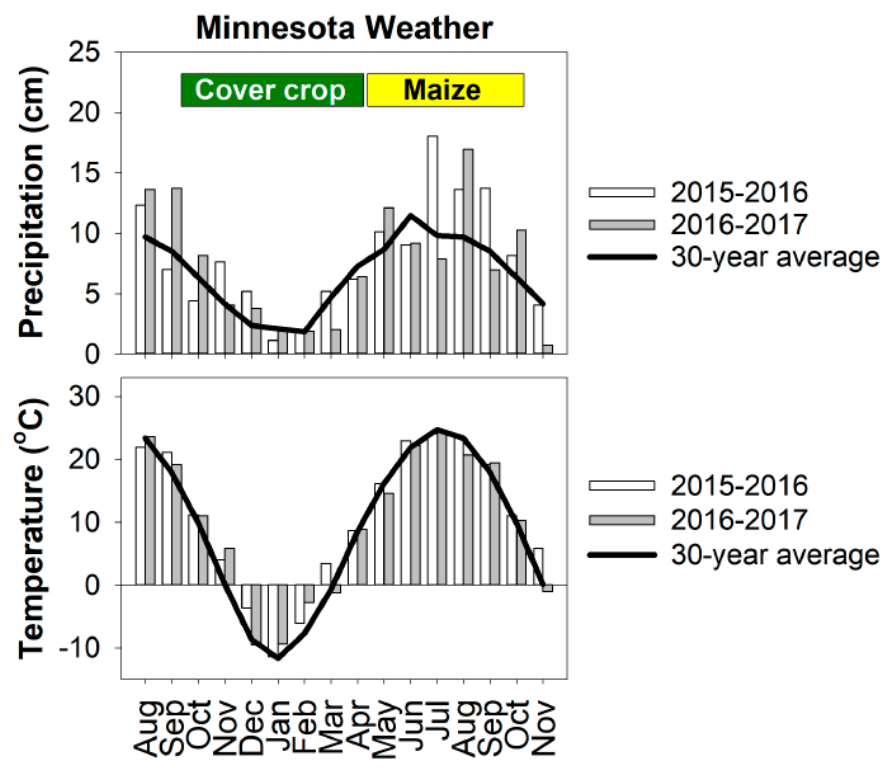

Figure 1. Average monthly precipitation $(\mathrm{cm})$ and temperature $\left({ }^{\circ} \mathrm{C}\right)$ during the study period compared with the 30-year mean for the period from 1981 to 2010. Data were averaged across nine National Weather Service weather stations in Minnesota.

Monthly average air temperature during winter (December through February) was normal or warmer than normal in both years. Precipitation was above average in both years in December, but near normal in January and February. On average, it was March when the 30-year temperature rose above the $3.3{ }^{\circ} \mathrm{C}$ threshold needed for rye vegetative growth to resume in the spring [45]. In 2016, it was warmer and wetter than usual, while in 2017 it was colder and drier than average. In April of both years, there was similar air temperature but lower precipitation than the 30-year average.

The maize growing season in both years had near-average temperatures, though precipitation was variable. In 2016, precipitation was above normal from May through October, with the exception of June. During this period, precipitation was $18.2 \mathrm{~cm}$ more than the 30-year average. In 2017, June, July, and September received below-normal precipitation while May, August, and October received more than average. From May through October, precipitation was $8.9 \mathrm{~cm}$ more than the 30-year average.

\subsection{Rye Biomass, Rye $\mathrm{N}$ Uptake, and Soil $\mathrm{NO}_{3}-\mathrm{N}$}

As indicated by spring biomass and density, recovery of rye following disturbance from manure injection was variable across sites (Figure 2, Table 3). The least disturbance occurred with smaller knives, with or without terminal sweeps. At most sites rye was terminated with herbicide and incorporated with tillage. Rye height at termination ranged from 5 to $30 \mathrm{~cm}$ among sites and was 25 to $30 \mathrm{~cm}$ at five sites (Table 3).

Aboveground rye DM at termination ranged from 102 to $3220 \mathrm{~kg} \mathrm{ha}^{-1}$. On average, rye growth was significantly greater $(p<0.001)$ in the 2016 maize growing season than in 2017 (mean of 1795 and $813 \mathrm{~kg} \mathrm{DM} \mathrm{ha}^{-1}$, respectively), perhaps because rye planting dates were earlier in 2015. Rye DM at termination was greater when rye was planted earlier (Figure 3). Across sites, aboveground DM declined by $413 \mathrm{~kg} \mathrm{ha}^{-1}$ with each one-week delay in rye planting. There was a significant positive linear relationship between rye DM $\left(\mathrm{kg} \mathrm{ha}^{-1}\right)$ and height $(\mathrm{cm})$ at termination $(\mathrm{y}=-444+99.88 \times \mathrm{x}$, $\mathrm{R}^{2}=0.76, p<0.001$ ). At termination, $\mathrm{N}$ concentration in aboveground $\mathrm{DM}$ ranged from 29 to $53 \mathrm{~g} \mathrm{~kg}^{-1}$ and was not linearly related to rye aboveground $\mathrm{DM}\left(\mathrm{R}^{2}=0.001, p=0.883\right)$, total rye biomass $\mathrm{N}$ $\left(R^{2}=0.28, p=0.490\right)$, or rye height $\left(R^{2}=0.008, p=0.712\right)$. Total $\mathrm{N}$ uptake was primarily determined by rye DM ( $\left.\mathrm{y}=2.25+0.038 \times \mathrm{x}, \mathrm{R}^{2}=0.92, p<0.001\right)$ and ranged from 5 to $114 \mathrm{~kg} \mathrm{ha}^{-1}$ (Table 2). 


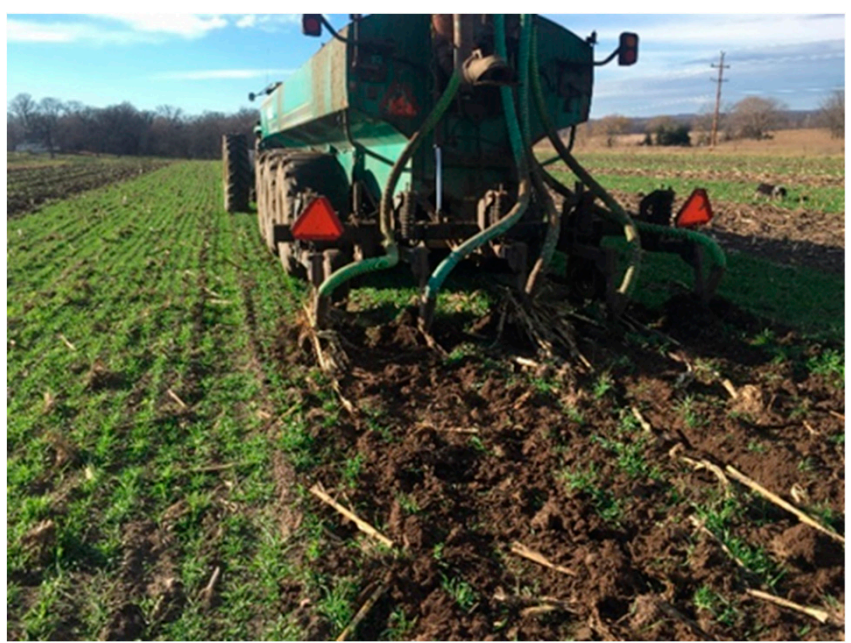

(a)

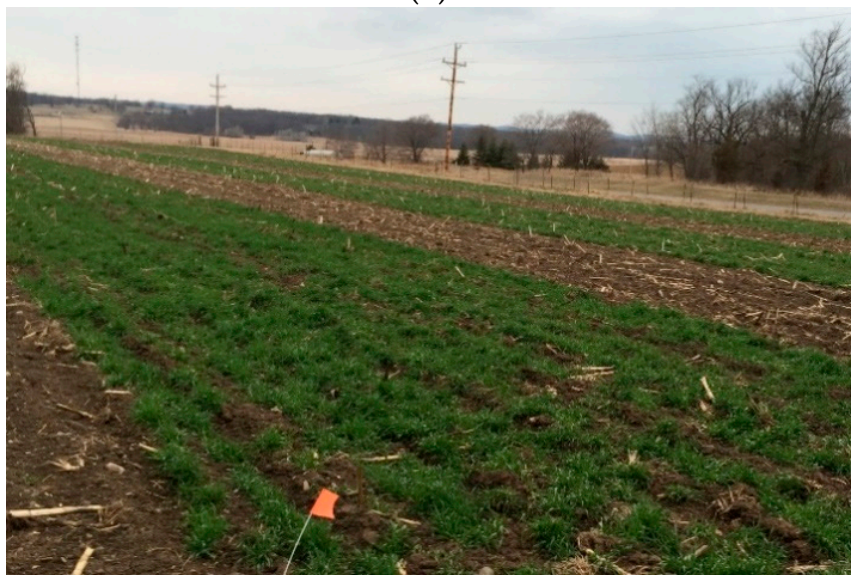

(b)

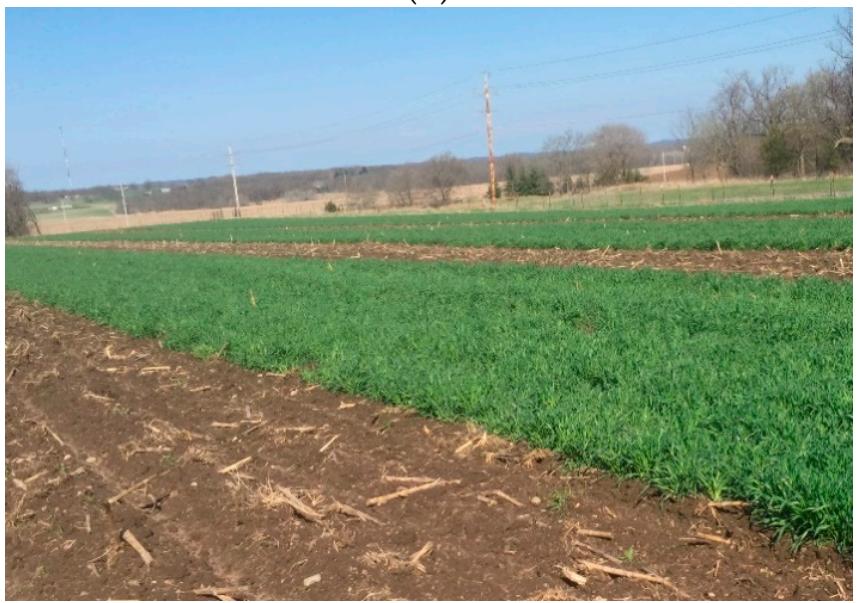

(c)

Figure 2. An example of rye recovery after manure injection at site 4 . Rye is shown at (a) manure injection in fall 2015, (b) two weeks after manure injection in fall 2015, and (c) at the time of termination in the spring of 2016. 
Table 3. Rye aboveground biomass dry matter (DM), height, and density at termination.

\begin{tabular}{|c|c|c|c|}
\hline Site & Biomass DM & Height * & Density \\
\hline & $\mathrm{kg} \mathrm{ha}^{-1}$ & $\mathrm{~cm}$ & Plants $\mathbf{m}^{-2}$ \\
\hline \multicolumn{4}{|c|}{2016 Maize Growing Season } \\
\hline 1 & $3220(572)+$ & 30 & $116(9)$ \\
\hline 2 & $1925(224)$ & 18 & $114(5)$ \\
\hline 3 & $408(34)$ & 13 & $120(8)$ \\
\hline 4 & $2526(55)$ & 25 & $128(7)$ \\
\hline 5 & $2622(301)$ & 30 & $138(7)$ \\
\hline 6 & $2002(43)$ & 28 & $74(4)$ \\
\hline 7 & $1853(160)$ & 28 & $71(6)$ \\
\hline 8 & $445(10)$ & 10 & $120(7)$ \\
\hline 9 & $1153(61)$ & 23 & $84(3)$ \\
\hline \multicolumn{4}{|c|}{2017 Maize Growing Season } \\
\hline 10 & $2141(213)$ & 15 & $160(7)$ \\
\hline 11 & $590(43)$ & 10 & $107(1)$ \\
\hline 12 & $1160(27)$ & 15 & $67(7)$ \\
\hline 13 & $160(5)$ & 8 & $122(6)$ \\
\hline 14 & 1760 (203) & 20 & $178(6)$ \\
\hline 15 & 609 (33) & 20 & $79(5)$ \\
\hline 16 & $102(18)$ & 5 & $51(1)$ \\
\hline 17 & $1300(92)$ & 15 & $181(2)$ \\
\hline 18 & $151(5)$ & 8 & $76(9)$ \\
\hline 19 & $160(10)$ & 8 & $104(4)$ \\
\hline
\end{tabular}

* Only one average measurement of height was made per site. + Standard error is shown within parentheses.

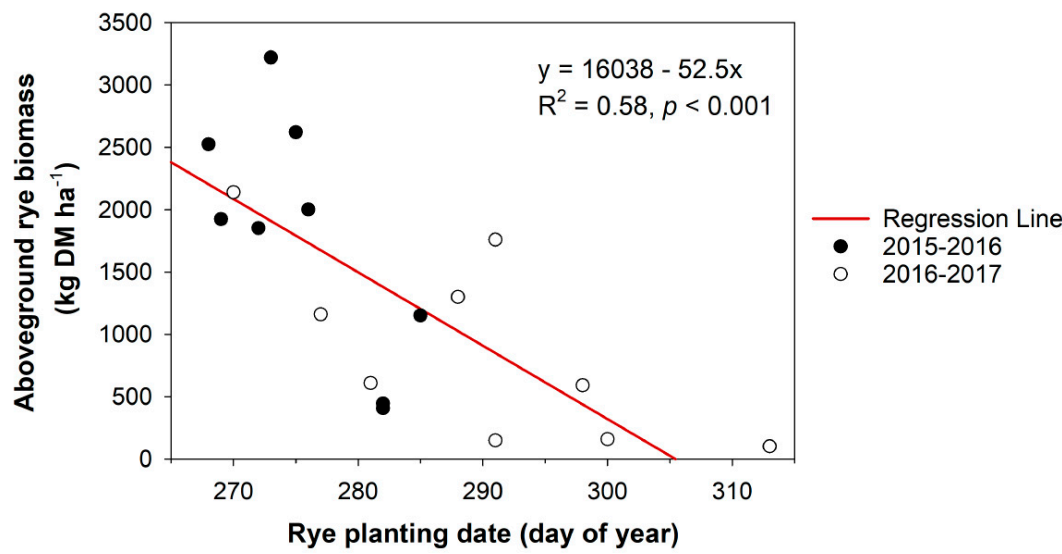

Figure 3. Aboveground rye biomass dry matter (DM) at termination in relation to rye planting date.

Across trials, the rye cover crop significantly reduced soil $\mathrm{NO}_{3}-\mathrm{N}$ in the $0-60 \mathrm{~cm}$ layer at rye termination compared to no rye (Table $2, p<0.001$ for treatments, $p=0.008$ for sites, $p=0.159$ for treatment $x$ site interaction). There were no differences within cover crop and no cover crop treatments when maize was the previous crop versus soybean $(p=0.494$ and 0.056 , respectively), nor when dairy manure was used versus swine manure ( $p=0.748$ and 0.113 , respectively). There was not a significant linear relationship between rye biomass and soil $\mathrm{NO}_{3}-\mathrm{N}$. The amount of $\mathrm{N}$ supplied by manure the previous fall varied considerably among sites (Table 2) so the amount of $\mathrm{NO}_{3}-\mathrm{N}$ available for uptake by the rye would have varied also. The amount of $\mathrm{N}$ taken up by the rye was not related to the difference between soil $\mathrm{NO}_{3}-\mathrm{N}$ in the rye and no-rye treatment in each trial. When the difference in soil $\mathrm{NO}_{3}-\mathrm{N}$ between cover cropped and bare plots was regressed on the number of days between rye planting and manure application, no significant relationship was found $(r=0.204, p=0.402)$. 


\subsection{Maize Silage and Grain Yields}

Across sites, maize silage and grain yields were not significantly influenced by cover cropping $(p=0.252$ and $p=0.422$, Tables 4 and 5). Similarly, there was no significant difference in maize $\mathrm{N}$ recovery in aboveground biomass with a winter rye cover crop compared to no cover crop $(p=0.412$, Table 2).

Table 4. Maize silage yield ( $\mathrm{Mg} \mathrm{ha}^{-1}$ at $650 \mathrm{~g} \mathrm{~kg}^{-1}$ moisture) in plots following rye and no rye.

\begin{tabular}{|c|c|c|}
\hline \multirow{2}{*}{ Site No. } & \multicolumn{2}{|c|}{ Silage Yield } \\
\hline & w/rye & w/o rye \\
\hline & \multicolumn{2}{|c|}{$\mathrm{Mg} \mathrm{ha}^{-1}$} \\
\hline 1 & $34.3(0.7)$ * & $39.8(0.5)$ \\
\hline 2 & $59.1(2.6)$ & $57.9(3.7)$ \\
\hline 4 & $48.1(0.9)$ & $46.5(2.5)$ \\
\hline 10 & $46.5(1.2)$ & 49.8 (1.9) \\
\hline 11 & $43.6(3.0)$ & $43.4(4.6)$ \\
\hline 12 & $39.0(0.9)$ & 41.5 (1.5) \\
\hline 14 & $48.6(2.5)$ & $48.6(0.0)$ \\
\hline 15 & $48.1(0.9)$ & $48.4(1.2)$ \\
\hline Mean & 45.7 (1.6) & 46.9 (1.4) \\
\hline
\end{tabular}

* Standard error is shown within parentheses. n.s. = not significantly different.

Table 5. Maize grain yield ( $\mathrm{Mg} \mathrm{ha}^{-1}$ at $155 \mathrm{~g} \mathrm{~kg}^{-1}$ moisture) and stalk dry matter in plots following rye and no rye.

\begin{tabular}{ccccc}
\hline \multirow{2}{*}{ Site No. } & \multicolumn{2}{c}{ Maize Grain Yield } & \multicolumn{2}{c}{ Maize Stalk Dry Matter } \\
\cline { 2 - 5 } & w/rye & w/o rye & w/rye & w/o rye \\
\hline & \multicolumn{5}{c}{ Mg ha $^{-1}$} \\
\hline 3 & $11.3(0.6)^{*}$ & $11.1(1.3)$ & $5.5(0.4)$ & $5.7(0.3)$ \\
6 & $12.4(0.1)$ & $11.8(0.2)$ & $8.4(0.3)$ & $7.9(0.3)$ \\
7 & $14.0(0.6)$ & $14.5(0.4)$ & $8.7(0.1)$ & $8.0(0.3)$ \\
8 & $13.8(0.0)$ & $14.1(0.1)$ & $7.2(0.5)$ & $6.6(0.2)$ \\
9 & $12.9(0.9)$ & $13.1(0.6)$ & $6.5(0.5)$ & $7.0(0.5)$ \\
13 & $10.0(0.3)$ & $10.5(0.2)$ & $5.1(0.4)$ & $6.1(0.2)$ \\
16 & $12.6(0.5)$ & $13.3(0.3)$ & $7.5(0.4)$ & $7.2(0.2)$ \\
17 & $10.2(0.1)$ & $10.3(0.3)$ & $7.2(0.3)$ & $8.0(0.1)$ \\
18 & $11.7(0.1)$ & $12.5(0.1)$ & $7.9(0.3)$ & $7.9(0.1)$ \\
19 & $14.4(0.3)$ & $13.7(0.4)$ & $7.5(0.4)$ & $7.3(0.2)$ \\
Mean & $13.8(0.5)$ & $13.8(0.4)$ & $7.7(0.2)$ & $7.6(0.2)$ \\
\hline Significance of difference with and without rye & $12.5(0.3)$ & $12.6(0.3)$ & $7.2(0.2)$ & $7.2(0.1)$ \\
\hline
\end{tabular}

* Standard error is shown within parentheses. n.s. = not significantly different.

\section{Discussion}

A winter rye cover crop was established in 2015 and 2016 across 19 trials in southern and central Minnesota using drill-seeding after maize silage or soybean harvest. In both years, rye recovered after fall liquid manure injection; however, wide disk coverers that disturbed or covered most of the soil surface (sites 6 and 12) were associated with low rye density at termination. Singer et al. found that although manure injection reduced rye density in the disturbed zone when using 5.1 -cm-wide chisel shanks, the rye biomass the following spring had fully recovered compared to the no-manure check [34]. Similarly, Milliron et al. reported that rye with manure injected with shallow disk injectors 
produced similar amounts of aboveground DM as when manure was applied prior to seeding the rye cover crop [35]. This illustrates the importance of using appropriate equipment that minimizes surface disturbance to reduce damage to a cover crop stand.

Rye establishment was more challenging in 2016 than in 2015 due to wide-spread precipitation which delayed harvest of the prior crop, indicating that post-harvest establishment of rye may not be successful in some years. An analysis of weather patterns in the upper Midwest USA by Strock et al. suggested that successful establishment post-harvest may only occur $25 \%$ of the time [46], although the paper only considered "successful" establishment to be the year when $2700 \mathrm{~kg} \mathrm{ha}^{-1}$ of aboveground rye biomass was produced. Only one site of 19 in the current study reported greater than this amount. Others in the region have reported lower amounts of aboveground DM production that likely reflect more realistic production goals. For example, rye DM production ranged from 147 to $489 \mathrm{~kg} \mathrm{ha}^{-1}$ by May 1 in southern Minnesota, USA [47]. In southwestern Minnesota, USA, Krueger et al. reported 680 to $872 \mathrm{~kg} \mathrm{ha}^{-1}$ of rye DM produced by late April [48]. In northwestern Iowa, USA, 1480 to $2740 \mathrm{~kg} \mathrm{ha}^{-1}$ of rye DM was produced by mid- to late-April when rye was drilled after harvest of the previous crop [49]. None of these researchers injected manure into the cover crop, potentially damaging the stand, however. In the current study which included manure injection, rye DM production tended to be similar to or higher than values in the literature in Minnesota, USA, and similar to those reported in Iowa, USA, which is further south and has a slightly warmer climate. This suggests the manure was beneficial for growth, despite possible damage to the rye stand during manure application.

One of the main goals of using a grass species for a cover crop is to capture nutrients that might otherwise be lost over the non-growing season. In this study, winter rye was successful in this regard. Not only did it hold $\mathrm{N}$ in the aboveground DM, differences were also found in spring soil $\mathrm{N}$ levels between the cover cropped and non-cover cropped treatments. Generally speaking, N uptake by the cover crop was related to DM production, which has been found in other studies as well [50,51]. This led to a wide range of total $\mathrm{N}$ uptake, from 4 to $114 \mathrm{~kg} \mathrm{~N} \mathrm{ha}^{-1}$, across the 19 sites. This variability is not uncommon in other cover crop studies. Rye $\mathrm{N}$ uptake ranged from 9 to $60 \mathrm{~kg} \mathrm{~N} \mathrm{ha}^{-1}$ in Nebraska [52], 11 to $26 \mathrm{~kg} \mathrm{~N} \mathrm{ha}^{-1}$ in Iowa [53], and 18.8 to $34.2 \mathrm{~kg} \mathrm{~N} \mathrm{ha}^{-1}$ in Minnesota [48]. Nitrogen taken up by the rye is less likely to be lost through agricultural sub-surface drainage or by leaching from the soil [22,46]. Rye reduced soil $\mathrm{NO}_{3}-\mathrm{N}$ in the $0-60 \mathrm{~cm}$ depth at the time of rye termination in the spring by an average of $36 \%$ across all 19 sites. There was considerable variability in the level of soil $\mathrm{NO}_{3}-\mathrm{N}$ among sites ( $p=0.008$ for sites), however. Similarly, Krueger et al. found that soil nitrate was reduced by approximately $35 \%$ with a rye cover crop compared with the no-cover control in Minnesota, USA [48]. Cambardella et al. found a slightly higher reduction of $41 \%$ in Iowa, USA, which has a warmer climate, with a rye/oat mix [54]. In the current study, variability across sites was likely due to differences in rye biomass production as well as site-specific weather and soil conditions. For example, higher than expected soil $\mathrm{NO}_{3}-\mathrm{N}$ concentration (based on the amount of $\mathrm{N}$ applied) in both cover cropped and bare plots may have been due to fall and spring mineralization of $\mathrm{N}$ from manure and soil organic matter. Where soil $\mathrm{NO}_{3}-\mathrm{N}$ concentration was lower than expected, there are two possible scenarios. Nitrogen in the ammonium form had not yet mineralized to $\mathrm{NO}_{3}-\mathrm{N}$ or the $\mathrm{NO}_{3}-\mathrm{N}$ was leached or denitrified during wet fall and/or spring conditions and lost.

Across sites, maize grain and silage yields were not affected by cover cropping. This may have been due to $\mathrm{N}$ supply exceeding the $\mathrm{N}$ requirements of maize throughout its growth cycle, as maize aboveground $\mathrm{N}$ uptake with a winter rye cover crop was not significantly different from that with no cover crop. In addition to $\mathrm{N}$ supply from manure (and fertilizer at 10 of 19 sites), a large amount of $\mathrm{N}$ was likely supplied by soil $\mathrm{N}$ mineralization. Soils at 15 of 19 sites were Mollisols, which have high $\mathrm{N}$ mineralization capacity compared to other soil orders [55], and soil organic matter was relatively high (42 to $83 \mathrm{~g} \mathrm{~kg}^{-1}$ in the $0-15 \mathrm{~cm}$ soil layer) at 15 of 19 sites and moderate ( 27 to $32 \mathrm{~g} \mathrm{~kg}^{-1}$ in the $0-15 \mathrm{~cm}$ soil layer) at the remaining sites. It is the general trend in most cover cropping studies that yields of the following crop are positively or minimally impacted [31,46,56-58], but others have found negative impacts on yield dependent on management technique. For example, Acharya et 
al. suggested that the timing of when the cover crop is killed may influence plant disease and stand establishment of the following crop [59]. Crandall et al. found that when termination was delayed to a week prior to planting maize and fertilizer application was delayed until the V6 growth stage, maize yield was decreased [42]. Other studies have suggested that there may be an alleopathic effect of rye $[60,61]$. Few studies have evaluated the impact of integrating fall-applied manure with cover crops on the following maize. Krueger et al. found that in a system with fall-applied dairy manure, rye terminated a few days prior to planting maize for silage reduced yields compared with rye terminated approximately three to four weeks earlier [48]. Thilakarathna et al. reported that in a fall-applied swine manure system, non-legume cover crops did not impact maize yields, although cereal rye was not evaluated [33]. In the current study, the cover crop was terminated at or before reaching $25 \mathrm{~cm}$ height and $2.5 \mathrm{Mg} \mathrm{ha}^{-1}$ dry matter at most sites, and then incorporated into the soil. Tillage incorporation of the cover crop may have facilitated $\mathrm{N}$ mineralization for the following crop [26,62] since different cover crop termination methods and timing may affect $\mathrm{N}$ availability for and performance of the subsequent maize crop [42,59]. It is also possible that mineralization of organically bound $\mathrm{N}$ from the manure offset immobilization of $\mathrm{N}$ by the rye cover crop early in the growing season. More research is needed to understand the dynamics of nutrient release from cover crops in a manured system.

\section{Conclusions}

In these 19 trials conducted in the upper Midwest USA, 15 of which were carried out by commercial growers with their own equipment and management, a rye cover crop was successfully established by drill-seeding following harvest of maize for silage or soybean. Although aboveground fall biomass was limited both by the short growth period prior to freezing and by disturbance from the manure injection equipment, spring growth was sufficient to result in significant $\mathrm{N}$ uptake. This study was conducted at sites with predominant occurrence of Mollisols and relatively high soil organic matter levels, hence high soil $\mathrm{N}$ mineralization capacity. This, coupled with termination of the rye prior to the reproductive stage by herbicide and tillage and subsequent release of $\mathrm{N}$, may have been partially responsible for the lack of yield reduction of the maize crop following rye compared to no rye. While removing $\mathrm{N}$ from exposure to leaching, as demonstrated in these trials as well as in earlier trials in Minnesota, USA [46], Iowa, USA [54] and Illinois, USA [57], the rye cover crop can also reduce soil erosion following the low residue crops of maize harvested for silage and soybean [63,64], an increasing threat as a changing climate in the Upper Midwest results in more intense rainstorms [65]. Reduced nitrate loss to groundwater and surface water and reduced soil erosion, increase the sustainability and reduce the environmental impact of the production system. Future research should focus on understanding the dynamics of nutrient release from grass legumes in a manured system.

Supplementary Materials: The following is available online at http://www.mdpi.com/2073-4395/9/12/852/s1, Table S1: Soil classification, texture, and initial soil-test levels $(0-15 \mathrm{~cm}$ depth) at 19 field research locations in Minnesota, USA, Table S2: Forms, rates, and dates of fertilizer nitrogen (N) application at the 10 sites where applied.

Author Contributions: Conceptualization, L.A.E. and R.J.P.; data curation, L.A.E. and M.L.W.; formal analysis, L.A.E. and J.A.C.; funding acquisition, L.A.E.; investigation, L.A.E. and R.J.P.; methodology, L.A.E. and R.J.P.; project administration, L.A.E.; resources, L.A.E. and R.J.P.; supervision, L.A.E.; validation, L.A.E., R.J.P., and J.A.C.; visualization, L.A.E., J.A.C., and M.L.W.; writing—original draft, L.A.E., M.L.W. and J.A.C.; writing一review and editing, L.A.E., M.L.W. and J.A.C.

Funding: This research was funded by a Section 319 grant from the U.S. Environmental Protection Agency through the Minnesota Pollution Control Agency, grant number 103675/PO3000015229, and by funds from the Minnesota Agricultural Experiment Station, University of Minnesota.

Acknowledgments: On-farm trials were carried out with the assistance of University of Minnesota Extension Educators Karen Anderson, Daniel Martens, Emily Wilmes, Sarah Sheick, Brenda Miller, Melissa Runck, Lizabeth Stahl, Diane DeWitt, Brad Carlson, Gregory Klinger, Jason Ertl, and Rodney Greder, as well as University of Minnesota West Central Research and Outreach Center faculty and staff Bradley Heins and Curt Reese. Thanks also to the agricultural growers who hosted the on-farm trials. 
Conflicts of Interest: The authors declare no conflicts of interest. The funders had no role in the design of the study; in the collection, analyses, or interpretation of data; in the writing of the manuscript, or in the decision to publish the results.

\section{References}

1. Diaz, R.J.; Rosenberg, R. Spreading Dead Zones and Consequences for Marine Ecosystems. Science 2008, 321, 926-929. [CrossRef] [PubMed]

2. $\quad$ Rabalais, N.N.; Turner, R.E.; Justić, D.; Dortch, Q.; Wiseman, W.J.; Gupta, B.K.S.; Justic, D. Nutrient Changes in the Mississippi River and System Responses on the Adjacent Continental Shelf. Estuaries 1996, 19, $386-407$. [CrossRef]

3. Goolsby, D.A.; Battaglin, W.A.; Lawrence, G.B.; Artz, R.S.; Aulenbach, B.T.; Hooper, R.P.; Keeney, D.R.; Stensland, G.J. Flux and Sources of Nutrients in the Mississippi-Atchafalaya River Basin: Topic 3 Report for the Integrated Assessment on Hypoxia in the Gulf of Mexico; NOAA/National Centers for Coastal Ocean Science: Silver Spring, MD, USA, 1999.

4. David, M.B.; Gentry, L.E.; Kovacic, D.A.; Smith, K.M. Nitrogen Balance in and Export from an Agricultural Watershed. J. Environ. Qual. 1997, 26, 1038-1048. [CrossRef]

5. Randall, G.W.; Mulla, D.J. Nitrate Nitrogen in Surface Waters as Influenced by Climatic Conditions and Agricultural Practices. J. Environ. Qual. 2001, 30, 337-344. [CrossRef] [PubMed]

6. Lawlor, P.A.; Helmers, M.J.; Baker, J.L.; Melvin, S.W.; Lemke, D.W. Nitrogen Application Rate Effect on Nitrate-Nitrogen Concentration and Loss in Subsurface Drainage for a Corn-Soybean Rotation. Trans. ASABE 2008, 51, 83-94. [CrossRef]

7. Sharpley, A.; Foy, B.; Withers, P. Practical and Innovative Measures for the Control of Agricultural Phosphorus Losses to Water: An Overview. J. Environ. Qual. 2000, 29, 1-9. [CrossRef]

8. McLellan, E.; Robertson, D.; Schilling, K.; Tomer, M.; Kostel, J.; Smith, D.; King, K. Reducing Nitrogen Export from the Corn Belt to the Gulf of Mexico: Agricultural Strategies for Remediating Hypoxia. J. Am. Water Resour. Assoc. 2015, 51, 263-289. [CrossRef]

9. Ribaudo, M.; Delgado, J.; Hansen, L.; Livingston, M.; Mosheim, R.; Williamson, J. Nitrogen in Agricultural Systems: Implications for Conservation Policy; United Statesd Department of Agriculture-Economic Research Service: Washington, DC, USA, 2011.

10. USDA-NASS. Crop. Production 2018 Summary; United Statesd Department of Agriculture-National Agricultural Statistics Service: Washington, DC, USA, 2019.

11. Minnesota Department of Agriculture. Fertilizer and Manure Selection and Management Practices Associated with Minnesota's 2010 Corn and Wheat Production; Minnesota Department of Agriculture: Saint Paul, MN, USA, 2014.

12. Minnesota Department of Agriculture. Commercial Nitrogen and Manure Applications on Minnesota's 2014 Corn Crop Compared to the University of Minnesota Nitrogen Guidelines; Minnesota Department of Agriculture: Saint Paul, MN, USA, 2014.

13. Andresen, J.; Hilberg, S.; Kunkel, K. Historical Climate and Climate Trends in the Midwestern USA. In U.S. National Climate Assessment Midwest Technical Input Report.; Winkler, J., Andresen, J., Hatfield, J., Bidwell, D., Brown, D., Eds.; Great Lakes Integrated Sciences and Assessments (GLISA) Center: Ann Arbor, MI, USA, 2012.

14. Abendroth, L.J.; Elmore, R.W.; Boyer, M.J.; Marlay, S.K. Corn Growth and Development; Iowa State University Extension: Ames, IA, USA, 2011.

15. American Society of Agricultural and Biological Engineers (ASABE). ASAE D384.2 Manure Production and Characteristics; American Society of Agricultural and Biological Engineers: St. Joseph, MI, USA, 2005; (R2019); pp. 1-32.

16. Sabey, B.R.; Bartholomew, W.V.; Shaw, R.; Pesek, J. Influence of Temperature on Nitrification in Soils. Soil Sci. Soc. Am. J. 1956, 20, 357-360. [CrossRef]

17. Chang, C.; Entz, T. Nitrate Leaching Losses Under Repeated Cattle Feedlot Manure Applications in Southern Alberta. J. Environ. Qual. 1996, 25, 145-153. [CrossRef]

18. Donner, S.D.; Kucharik, C.J.; Foley, J.A. Impact of Changing Land Use Practices on Nitrate Export by the Mississippi River. Glob. Biogeochem. Cycles 2004, 18. [CrossRef] 
19. Novotny, E.V.; Stefan, H.G. Stream Flow in Minnesota: Indicator of Climate Change. J. Hydrol. 2007, 334, 319-333. [CrossRef]

20. Ditsch, D.C.; Alley, M.M.; Kelley, K.R.; Lei, Y.Z. Effectiveness of Winter Rye for Accumulating Residual Fertilizer N Following Corn. J. Soil Water Conserv. 1993, 48, 125-132.

21. Coale, F.J.; Costa, J.M.; Bollero, G.A.; Schlosnagle, S.P. Small Grain Winter Cover Crops for Conservation of Residual Soil Nitrogen in the Mid-Atlantic Coastal Plain. Am. J. Altern. Agric. 2001, 16, 66-72. [CrossRef]

22. McCracken, D.V.; Smith, M.S.; Grove, J.H.; Blevins, R.L.; MacKown, C.T. Nitrate Leaching as Influenced by Cover Cropping and Nitrogen Source. Soil Sci. Soc. Am. J. 1994, 58, 1476-1483. [CrossRef]

23. Shah, S.; Hookway, S.; Pullen, H.; Clarke, T.; Wilkinson, S.; Reeve, V.; Fletcher, J.M. The Role of Cover Crops in Reducing Nitrate Leaching and Increasing Soil Organic Matter. Asp. Appl. Biol. 2017, 134, 243-251.

24. Meisinger, J.J.; Ricigliano, K.A. Nitrate Leaching from Winter Cereal Cover Crops Using Undisturbed Soil-Column Lysimeters. J. Environ. Qual. 2017, 46, 576-584. [CrossRef]

25. Huntington, T.G.; Grove, J.H.; Frye, W.W. Release and Recovery of Nitrogen from Winter Annual Cover Crops in No-till Corn Production. Commun. Soil Sci. Plant. Anal. 1985, 16, 193-211. [CrossRef]

26. Jahanzad, E.; Barker, A.V.; Hashemi, M.; Eaton, T.; Sadeghpour, A.; Weis, S.A. Nitrogen Release Dynamics and Decomposition of Buried and Surface Cover Crop Residues. Agron. J. 2016, 108, 1735-1741. [CrossRef]

27. Finney, D.M.; White, C.M.; Kaye, J.P. Biomass Production and Carbon/Nitrogen Ratio Influence Ecosystem Services from Cover Crop Mixtures. Agron. J. 2016, 108, 39-52. [CrossRef]

28. Miguez, F.E.; Bollero, G.A. Review of Corn Yield Response under Winter Cover Cropping Systems Using Meta-Analytic Methods. Crop Sci. 2005, 45, 2318-2329. [CrossRef]

29. Gabriel, J.L.; Quemada, M. Replacing Bare Fallow with Cover Crops in a Maize Cropping System: Yield, N Uptake and Fertiliser Fate. Eur. J. Agron. 2011, 34, 133-143. [CrossRef]

30. Ball-Coelho, B.R.; Roy, R.C. Overseeding Rye into Corn Reduces $\mathrm{NO}_{3}$ Leaching and Increases Yields. Can. J. Soil Sci. 1997, 77, 443-451. [CrossRef]

31. Ball Coelho, B.R.; Roy, R.C.; Bruin, A.J. Long-Term Effects of Late-Summer Overseeding of Winter Rye on Corn Grain Yield and Nitrogen Balance. Can. J. Plant. Sci. 2005, 85, 543-554. [CrossRef]

32. Komainda, M.; Taube, F.; Kluß, C.; Herrmann, A. Effects of Catch Crops on Silage Maize (Zea mays L.): Yield, Nitrogen Uptake Efficiency and Losses. Nutr. Cycl. Agroecosyst. 2018, 110, 51-69. [CrossRef]

33. Thilakarathna, M.S.; Serran, S.; Lauzon, J.; Janovicek, K.; Deen, B. Management of Manure Nitrogen Using Cover Crops. Agron. J. 2015, 107, 1595-10607. [CrossRef]

34. Singer, J.W.; Cambardella, C.A.; Moorman, T.B. Enhancing Nutrient Cycling by Coupling Cover Crops with Manure Injection. Agron. J. 2008, 100, 1735-1739. [CrossRef]

35. Milliron, R.A.; Karsten, H.D.; Beegle, D.B. Influence of Dairy Slurry Manure Application Method, Fall Application-Timing, and Winter Rye Management on Nitrogen Conservation. Agron. J. 2019, 111, 1-15. [CrossRef]

36. Laverty, J.C. A Modified Procedure for Determination of Phosphorus in Soil Extracts. Soil Sci. Soc. Am. Proc. 1963, 27, 360-361. [CrossRef]

37. Frank, K.; Beegle, D.; Denning, J. Phosphorus. In Recommended Chemical Soil Test Procedures for the North Central Region; Brown, J.R., Ed.; Missouri Agricultural Experiment Station SB 1001: Columbia, MO, USA, 1998.

38. Warncke, D.; Brown, J.R. Potassium and Other Basic Cations. In Recommended Chemical Soil Test Procedures for the North Central Region; Brown, J.R., Ed.; Missouri Agricultural Experiment Station SB 1001: Columbia, MO, USA, 1998.

39. Peters, J.B.; Nathan, M.V.; Laboski, C.A.M. PH and Lime Requirement. In Recommended Chemical Soil Test Procedures for the North Central Region; Brown, J.R., Ed.; Missouri Agricultural Experiment Station SB 1001: Columbia, MO, USA, 1998.

40. Combs, S.M.; Nathan, M.V. Soil Organic Matter. In Recommended Chemical Soil Test Procedures for the North Central Region; Brown, J.R., Ed.; Missouri Agricultural Experiment Station SB 1001: Columbia, MO, USA, 1998.

41. Peters, J.; Combs, S.; Hoskins, B.; Jarman, J.; Kovar, J.; Watson, M.; Wolf, A.; Wolf, N. Recommended Methods of Manure Analysis; Peters, J., Ed.; Cooperative Extension Publishing: Madison, WI, USA, 2003.

42. Crandall, S.M.; Ruffo, M.L.; Bollero, G.A. Cropping System and Nitrogen Dynamics under a Cereal Winter Cover Crop Preceding Corn. Plant. Soil 2005, 268, 209-219. [CrossRef]

43. Gelderman, R.H.; Beegle, D. Nitrate-Nitrogen. In Recommended Chemical Soil Test Procedures for the North Central Region; Brown, J.R., Ed.; Missouri Agricultural Experiment Station SB 1001: Columbia, MO, USA, 1998. 
44. Huffman, S.A.; Barbarick, K.A. Soil Nitrate Analysis by Cadmium Reduction. Commun. Soil Sci. Plant. Anal. 1981, 12, 79-89. [CrossRef]

45. SARE. Managing Cover Crops Profitably, 3rd ed.; Sustainable Agriculture Research and Education (SARE): College Park, MD, USA, 2012.

46. Strock, J.S.; Porter, P.M.; Russelle, M.P. Cover Cropping to Reduce Nitrate Loss through Subsurface Drainage in the Northern U.S. Corn Belt. J. Environ. Qual. 2004, 33, 1010-1016. [CrossRef] [PubMed]

47. De Bruin, J.L.; Porter, P.M.; Jordan, N.R. Use of a Rye Cover Crop Following Corn in Rotation with Soybean in the Upper Midwest. Agron. J. 2005, 97, 587-598. [CrossRef]

48. Krueger, E.S.; Ochsner, T.E.; Porter, P.M.; Baker, J.M. Winter Rye Cover Crop Management Influences on Soil Water, Soil Nitrate, and Corn Development. Agron. J. 2011, 103, 316-323. [CrossRef]

49. Kaspar, T.C.; Jaynes, D.B.; Parkin, T.B.; Moorman, T.B. Rye Cover Crop and Gamagrass Strip Effects on NO3 Concentration and Load in Tile Drainage. J. Environ. Qual. 2007, 36, 1503-1511. [CrossRef] [PubMed]

50. Wilson, M.L.; Baker, J.M.; Allan, D.L. Factors Affecting Successful Establishment of Aerially Seeded Winter Rye. Agron. J. 2013, 105, 1868-1877. [CrossRef]

51. Clark, A.J.; Decker, A.M.; Meisinger, J.J.; McIntosh, M.S. Kill Date of Vetch, Rye, and a Vetch-Rye Mixture: I. Cover Crop and Corn Nitrogen. Agron. J. 1997, 89, 427-434. [CrossRef]

52. Kessavalou, A.; Walters, D.T. Winter Rye Cover Crop Following Soybean Under Conservation Tillage. Agron. J. 1999, 91, 643-649. [CrossRef]

53. Pantoja, J.L.; Woli, K.P.; Sawyer, J.E.; Barker, D.W. Corn Nitrogen Fertilization Requirement and Corn-Soybean Productivity with a Rye Cover Crop. Soil Sci. Soc. Am. J. 2015, 79, 1482-1895. [CrossRef]

54. Cambardella, C.A.; Moorman, T.B.; Singer, J.W. Soil Nitrogen Response to Coupling Cover Crops with Manure Injection. Nutr. Cycl. Agroecosyst 2010, 87, 383-393. [CrossRef]

55. Brady, N.; Weil, R. The Nature and Properties of Soils, 13th ed.; Pearson/Prentice Hall: Upper Saddle River, NJ, USA, 2002.

56. Basche, A.D.; Kaspar, T.C.; Archontoulis, S.V.; Jaynes, D.B.; Sauer, T.J.; Parkin, T.B.; Miguez, F.E. Soil Water Improvements with the Long-Term Use of a Winter Rye Cover Crop. Agric. Water Manag. 2016, 172, 40-50. [CrossRef]

57. Ruffo, M.L.; Bullock, D.G.; Bollero, G.A. Soybean Yield as Affected by Biomass and Nitrogen Uptake of Cereal Rye in Winter Cover Crop Rotations. Agron. J. 2004, 96, 800-805. [CrossRef]

58. Duiker, S.W.; Curran, W.S. Rye Cover Crop Management for Corn Production in the Northern Mid-Atlantic Region. Agron. J. 2005, 97, 1413-1418. [CrossRef]

59. Acharya, J.; Bakker, M.G.; Moorman, T.B.; Kaspar, T.C.; Lenssen, A.W.; Robertson, A.E. Time Interval Between Cover Crop Termination and Planting Influences Corn Seedling Disease, Plant Growth, and Yield. Plant. Dis. 2017, 101, 591-600. [CrossRef] [PubMed]

60. Raimbault, B.A.; Vyn, T.J.; Tollenaar, M. Corn Response to Rye Cover Crop Management and Spring Tillage Systems. Agron. J. 1990, 82, 1088-1093. [CrossRef]

61. Tollenaar, M.; Mihajlovic, M.; Vyn, T.J. Annual Phytomass Production of a Rye-Corn Double-Cropping System in Ontario. Agron. J. 1992, 84, 963-967. [CrossRef]

62. Wilson, D.O.; Hargrove, W.L. Release of Nitrogen from Crimson Clover Residue under Two Tillage Systems1. Soil Sci. Soc. Am. J. 1986, 50, 1251-1254. [CrossRef]

63. Kaspar, T.C.; Radke, J.K.; Laflen, J.M. Small Grain Cover Crops and Wheel Traffic Effects on Infiltration, Runoff, and Erosion. J. Soil Water Conserv. 2001, 56, 160-164.

64. De Baets, S.; Poesen, J.; Meersmans, J.; Serlet, L. Cover Crops and Their Erosion-Reducing Effects during Concentrated Flow Erosion. Catena 2011, 85, 237-244. [CrossRef]

65. Easterling, D.R.; Kunkel, K.E.; Arnold, J.R.; Knutson, T.; Legrande, A.N.; Leung, L.R.; Vose, R.S.; Wal-Iser, D.E.; Wehner, M.F.; Fahey, D.J.W.; et al. Precipitation Change in the United States; Wuebbles, D.J., Fahey, D.W., Hibbard, K.A., Dokken, D.J., Stewart, B.C., Maycock, T.K., Eds.; U.S. Global Change Research Program: Washington, DC, USA, 2017. [CrossRef]

(C) 2019 by the authors. Licensee MDPI, Basel, Switzerland. This article is an open access article distributed under the terms and conditions of the Creative Commons Attribution (CC BY) license (http://creativecommons.org/licenses/by/4.0/). 